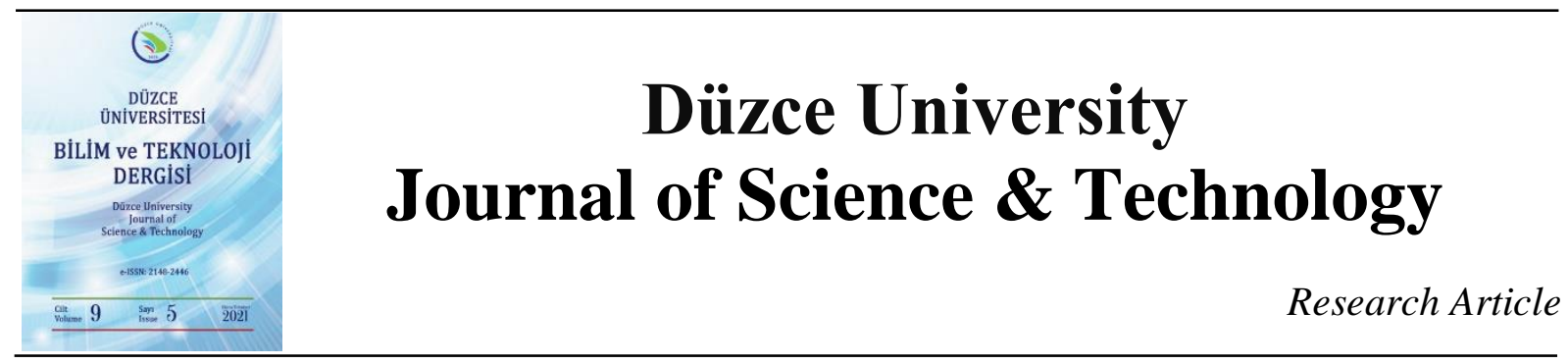

\title{
Slope Stability Evaluation of Basement Excavation: A Case Study
}

\author{
Ahmet ERDAĞ $\breve{G}^{\mathrm{a},}{ }^{*}$ \\ ${ }^{a}$ Department of Civil Engineering, Faculty of Technology, Gazi University, Ankara, TURKEY \\ * Corresponding author's e-mail address: ahmeterdag@gazi.edu.tr
}

DOI: 10.29130/dubited.913351

\begin{abstract}
A deep excavation should be designed and implemented together with the precautions to prevent any loss of stability and structural damage in the infrastructure and superstructure elements of the neighboring parcels and risks against construction worker's health and safety. This study represents an example of soil damage that may occur due to foundation excavation. The features of the soil affected by the excavation were analyzed through a geological survey and soil models were created for each analysis stages. The study investigates the slope stability analyses that take place during the foundation excavation with the commonly used limit equilibrium (LE) methods. In this article, slope problems that may occur around the excavation before the construction of the basement of a 3 -storey school building in Istinye Neighborhood of Istanbul Sariyer district are examined. First, geotechnical and structural parameters were determined by obtaining detailed drilling reports of the region. Then the study area was modeled with the Rocscience Slide 6.0 program based on the limit equilibrium method. Following the evaluation of the basement excavations, a beveled excavation was made for the safety of the basement construction after the excavation and the stability of the slope excavations was found to be sufficient.
\end{abstract}

Keywords: Limit equilibrium method, Slope stability analysis, Excavation, School construction

\section{Bodrum Kazısının Şev Stabilite Değerlendirmesi: Vaka Analizi}

\begin{abstract}
$\underline{\mathrm{OZZ}}$
Bir derin kazı işleminin komşu parsellerdeki alt ve üst yapı unsurlarında veya arsalarda herhangi bir stabilite kaybına ve yapısal hasarlara neden olmaması, inşaat işçi sağlığı ve güvenliği riski yaratmaması için önlemleriyle birlikte projelendirilmesi ve uygulanması gerekmektedir. Bu çalışma, temel kazısı nedeniyle oluşabilecek zemin hasarlarının bir örneğini temsil etmektedir. Kazı ile etkilenen zeminin özellikleri jeolojik araştırma yoluyla analiz edilmiştir ve farklı analiz aşamalar için zemin modelleri oluşturulmuştur. Çalışma, yaygın olarak kullanılan limit denge (LE) yöntemleriyle temel kazısında meydana gelebilecek şev stabilitesi analizlerini ele almaktadır. Bu makalede İstanbul Sarıyer ilçesi İstinye Mahallesi'ndeki 3 katlı bir okul binasının bodrum katının inşasından önce kazı çevresinde meydana gelebilecek şev problemleri incelenmiştir. Bölgeye ait detaylı sondaj raporları alınarak geoteknik ve yapısal parametreler belirlenmiş, çalışma alanı limit denge yöntemine dayalı Rocscience Slide 6.0 programı ile modellenerek bodrum kazıları değerlendirme sonucunda kazı sonrası bodrum inşası güvenliği için şevli kazı yapılmıştır ve şevli kazıların stabilite analizi sonucu eğim güvenliğinin yeterli olduğu tespit edilmiştir.
\end{abstract}

Anahtar Kelimeler: Limit denge yöntemi, Şev stabilite analizi, Kazı, Okul inşaatı 


\section{INTRODUCTION}

Istanbul is Turkey's largest metropolis and a global city with a population of about 15 million. It also hosts half of the country's industrial potential. In addition to its natural state, earthquake risk in the city has increased owing to overpopulation, inaccurate land use planning and construction, inadequate infrastructure, services and environmental degradation [1]. Istanbul is experiencing a rapid urban transformation and development process due to globalization. Most of the existing buildings and urban textures are no longer suitable for a city and its residents with a great risk of earthquakes [2].

A city's development process may necessitate pre-construction analyses for structural health during the demolition of a building/area and the construction of new ones. One of these analyses is soil stability analysis. The effect of excavation on the stability of cut slope has been a current issue. Many studies have found that the failure on cut slopes is associated with stress release induced by excavation $[3,4]$.

A realistic assessment when examining stability on slopes requires a detailed engineering study that includes extensive field and laboratory investigations. [5]. Stability is closely related to various geoenvironmental factors such as geology, geomorphology and land cover [6,7]. It is often triggered by human intervention, heavy rainfall, and some other dynamic variables [8-10]. Excavation-induced landslides are encountered in construction excavations as well as mining operations [11]. Human activities in particular have been accepted as an important triggering factor leading to many ground problems in excavations $[12,13]$.

Slope failure caused by excavation in the construction of civil engineering such as geology engineering, building engineering and highway engineering is one of the common engineering disasters [14-16]. During excavation work of natural slopes, the slope face may deform and this can lead to slope failure. Figure 1 shows common slope failures as a result of excavation [17].

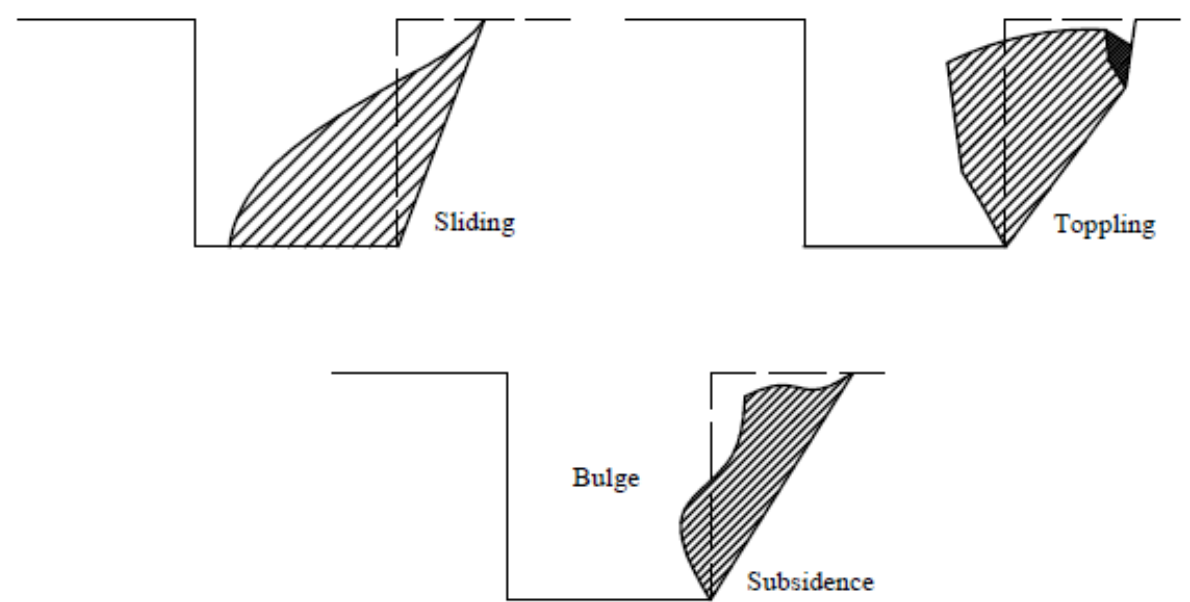

Figure 1. Different pattern of ground movement (drawn by the author).

The Hürriyet Elementary School building, located within the boundaries of Istanbul's Sariyer district, İstinye Neighborhood, was demolished and replaced by a new school building with 4 floors (2nd basement +1 st basement + ground floor +1 st floor). The characteristics and reasons for the problems in the soil were determined by geological research and numerical modeling for the safety of the excavation. As a result of geological research, the stability situation was simulated after each excavation using Rocscience Slide 6.0 software and performed by numerical modeling. Physical conditions in the newly built school building have been improved, social areas have been expanded and it has started to serve as of 2017. 


\section{STUDY AREA}

The study area is located in the Sariyer region and has an average height of $180 \mathrm{~m}$ above sea level (Figure 2). The investigated area is located in the northern part of Istanbul and confined by Latitudes $41^{\circ} 7.882^{\prime} \mathrm{N}$ and Longitudes $29^{\circ} 2.322^{\prime} \mathrm{E}$ [18]. The land with an inclined structure, rises with a certain elevation between 64.10 meters and 81.78 meters. There is a forest and green area in the northeastern part of the land and a forest tourism area in the northwest. The current status of the study area is shown in Figure 3a.

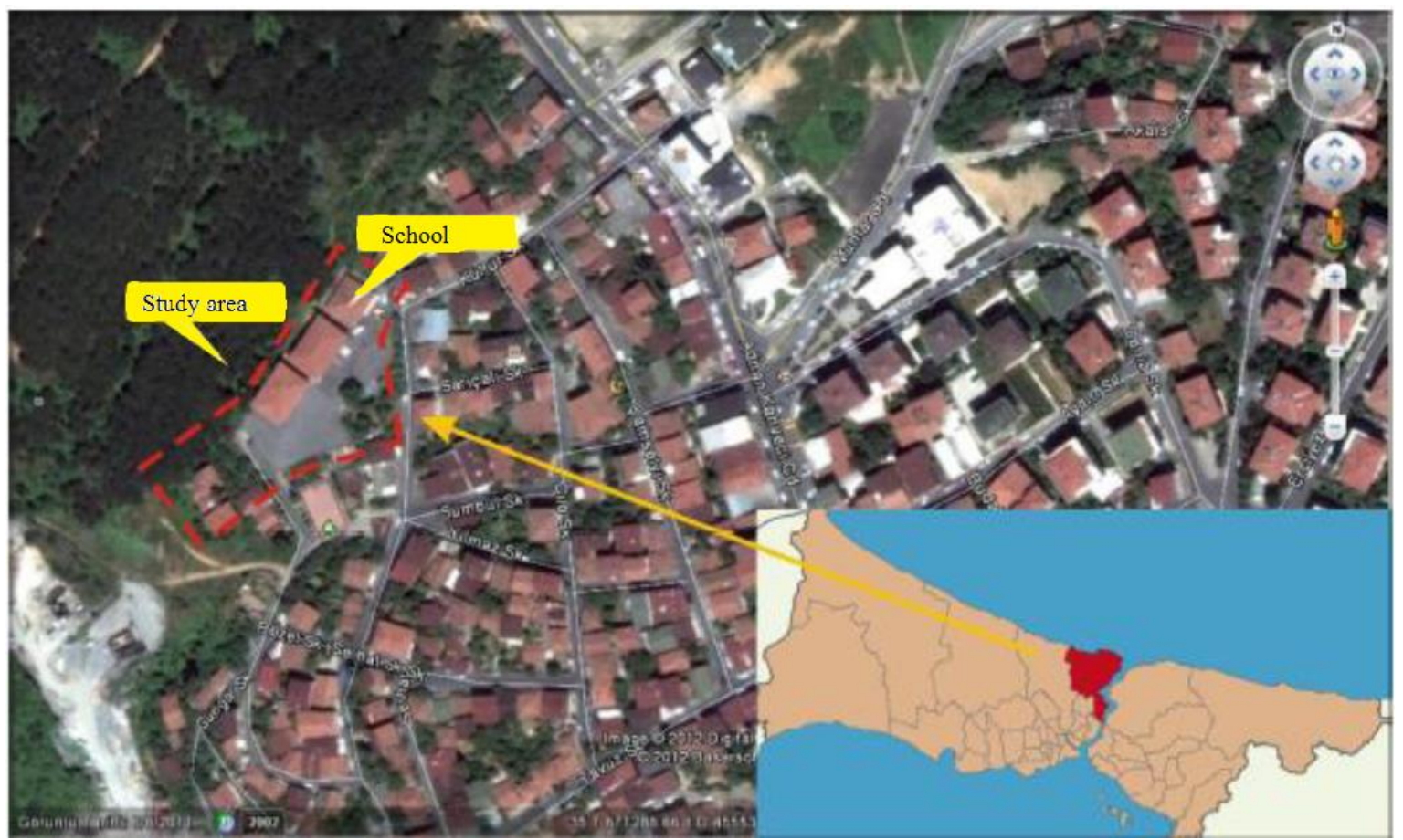

Figure 2. Location map where the study area is located [18].

The upper cretaceous clastic and volcanic rock assemblage extending roughly to the Black Sea coast between Şile and Karaburun on both sides of the Bosphorus has been studied by different researchers. It has been suggested that the name of Sariyer district, which is located on the area consisting of clastic and volcanic, remains the name of the formation for the whole sequence. Sariyer formation consists of marl conglomerate containing volcanic tuff, andesite and agglomerate additives. The lower parts of the unit show volcanic flysch characteristics. Overall, the Saryer formation is an earthquake-resistant, solid formation. However, there are regions that are weathered, that is, weak against earthquakes in this formation too [19].

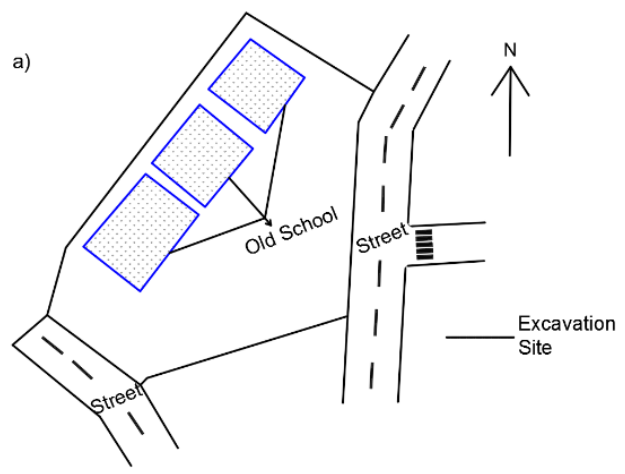

(a)

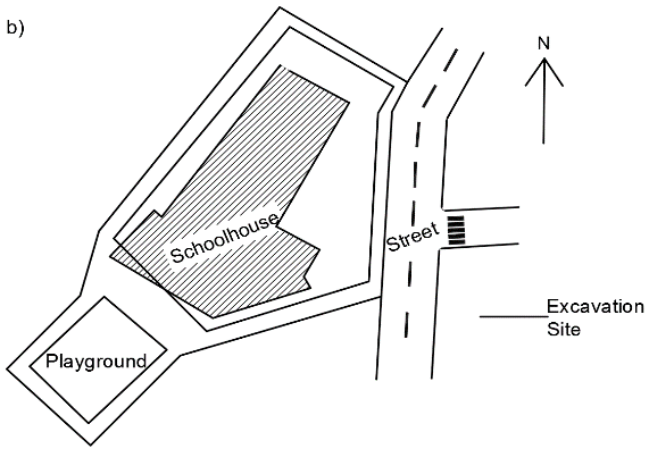

(b)

Figure 3. Current status of the study area (a) New school plan (b) (drawn by the author). 
The settlement of the newly built school building structure on the land is provided in Figure $3 \mathrm{~b}$. The school building was constructed at a distance of at least 3 meters from the side parcels and green areas.

\section{FIELD RESEARCH AND DRILLING}

Four boreholes with a depth of 20 meters and a total length of 80 meters were drilled in the study area. Soil stratification is divided into two layers. Groundwater levels were found between 7.00 and 7.20 meters in the boreholes. The location of the boreholes and the basement excavations are given in Figure 4.

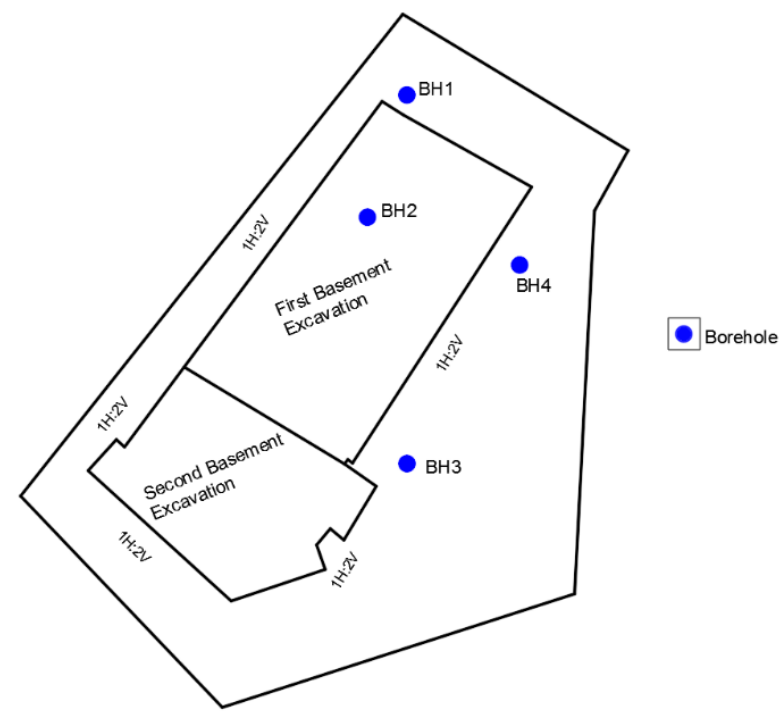

Figure 4. Field survey and drilling (drawn by the author).

The generalized soil profiles and geotechnical properties of these four boreholes named $\mathrm{BH} 1, \mathrm{BH} 2, \mathrm{BH} 3$ and $\mathrm{BH} 4$ are given below. Also, the ground stratification is shown in Figure 5.

- Borehole (BH) 1

There is a layer of pebbly sandy clay between 0.00-16.00 meters and a layer of pebbly clayey sand between 16.00 and 20.00 meters. The soil class has been found as SC - CL in laboratory tests performed on samples taken from this drill.

- Borehole (BH) 2

There is a layer of pebbly sandy clay between 0.00-16.00 meters and a layer of pebbly clayey sand between 16.00 and 20.00 meters. The soil class has been found as SC - CL in laboratory tests performed on samples taken from this drill.

- Borehole (BH) 3

A layer of gravelly sandy clay extends between $0.00-20.00$ meters. The soil class has been found as CL in laboratory tests performed on samples taken from this drill.

- Borehole (BH) 4

There is a layer of pebbly sandy clay between 0.00-12.00 meters and a layer of pebbly clayey sand between 12.00-20.00meters. The soil class has been found as SC - CL in laboratory tests performed on samples taken from this drill. 


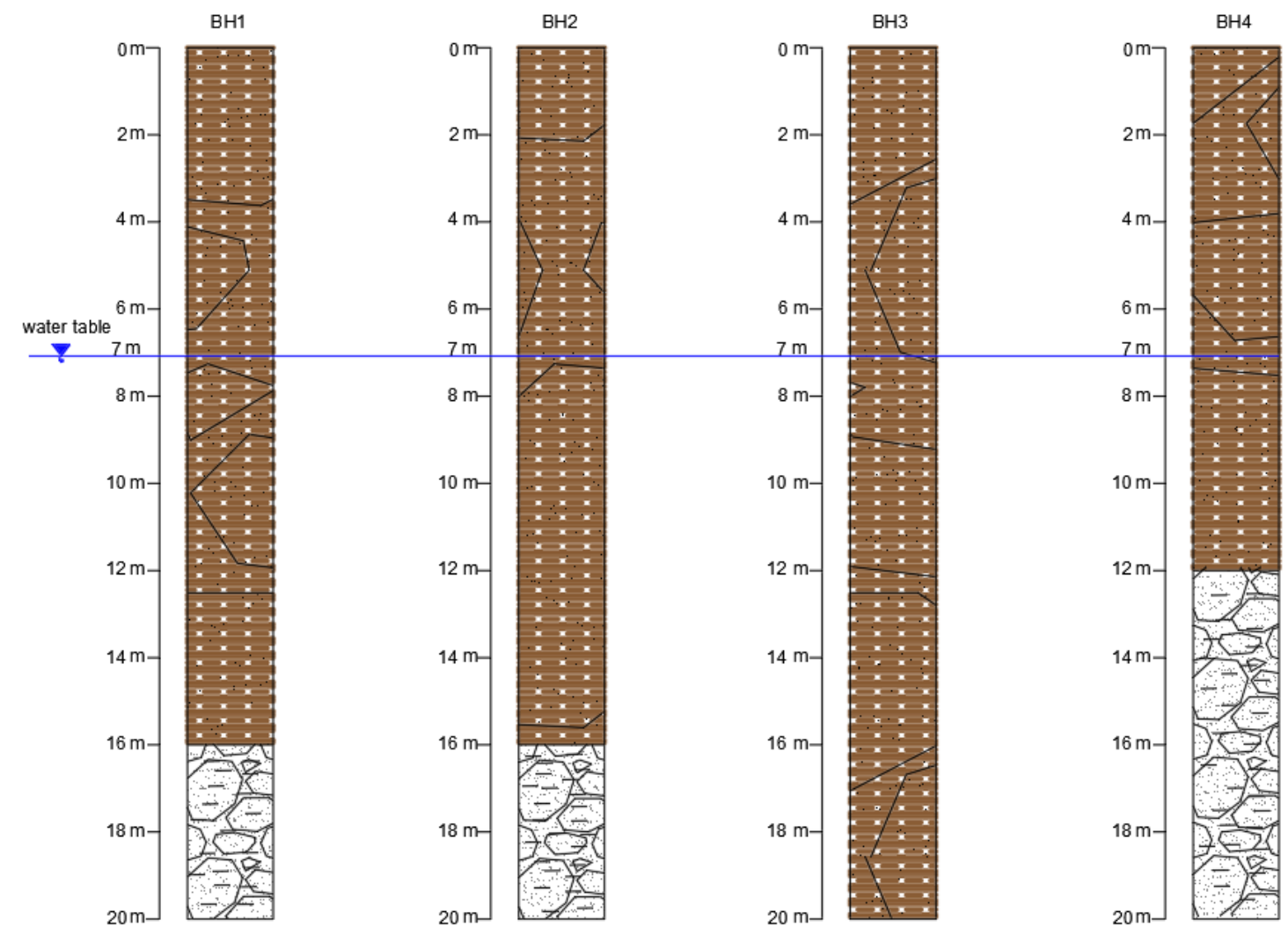

Figure 5. Soil strata from borehole log profiles (drawn by the author).

\section{SELECTION OF SOIL PARAMETERS}

Strength parameters are taken from geological-geotechnical report and literature and idealized for the relevant sections. The sandy clay unit has been considered as the idealized ground. In the calculations, BH-4 drilling UD sample values $\mathrm{c}=55.47 \mathrm{kNm}^{-2}$ and $\varphi^{\circ}=10$ were used. Sample values were obtained from ground samples. However, since there is a groundwater level on the ground after 7.20 meters, the strength parameters will be reduced by the reduction coefficients given in the literature. Terzaghi bearing capacity strength reduction method was used for local slope failure.

Terzaghi bearing capacity strength reduction:

Terzaghi proposed in equation 1 and equation 2 that bearing capacity factors, a modified friction angle and cohesion values can be used for local slope failure when the ground is weak or in other words not very dense and hard $[20,21]$.

$c^{\prime}=0.67 \times c$

$\varphi^{\prime}=\tan ^{-1} x(0.67 x \tan \varphi)$

The ground parameters used in the analysis are given in Table 1 together with the modified cohesion and internal friction angle values of the equation results. 
Table 1. Values of soil parameters used in slide analyses.

\begin{tabular}{l|l}
\hline Parameter & Value \\
\hline Unit weight, $\gamma\left(\mathrm{kN} / \mathrm{m}^{3}\right)$ & 19 \\
\hline Cohesion, $c(\mathrm{kN} / \mathrm{m} 2)$ & 37.16 \\
\hline Friction angle, $\varphi\left(^{\circ}\right)$ & 6.73 \\
\hline Poisson's ratio, $v$ & 0.25 \\
\hline
\end{tabular}

\section{V.METHODOLOGY}

Based on the evaluations made, it has been observed that the 1st basement excavation (Figure 6) started from approximately 71.50 elevations and continued up to the highest level of 78.00. In this case, the 2nd basement floor excavation was calculated as 7.30 meters $(78.00-70.70=7.30)$ at the maximum point. For this excavation, there is a setback distance of approximately 6.60 meters on the side facades. However, since the foundation of the part used as a kindergarten where the building is separated by dilatation will settle, a vertical curtain excavation was made. In this case, a beveled excavation with a $1 \mathrm{H} / 2 \mathrm{~V}$ inclination is proposed for facades with optional slopes.

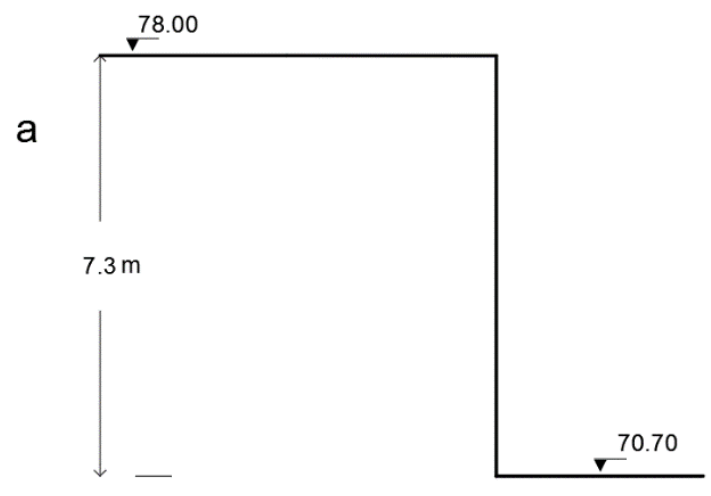

(a)

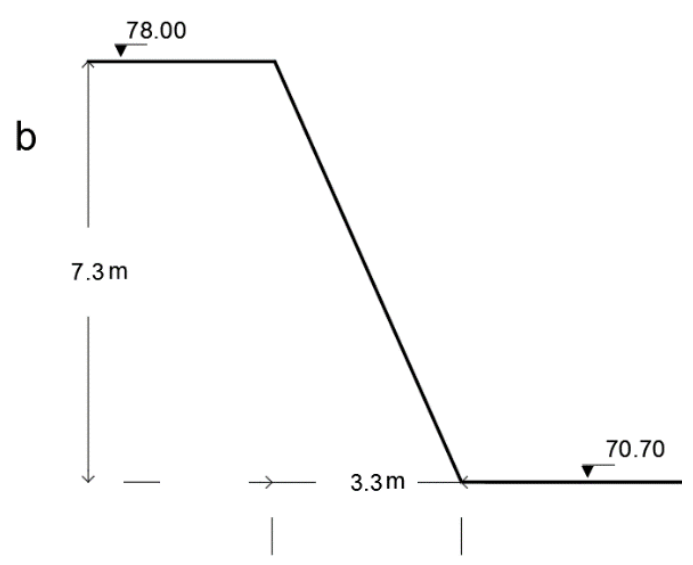

(b)

Figure 6. $\boldsymbol{a}$ and $\boldsymbol{b}$ maximum elevation sections to be formed during 1 st basement excavation.

2nd basement floor excavation (Figure 7) was calculated as 5.00 meters $(71.50-66.50=5.00)$ at the maximum point. For this excavation, there is a setback distance of approximately 5 meters on the side facades. However, since the foundation of the first basement part will settle in the section where the building is separated by dilatation, it is not recommended to excavate with an optional slope of $1 \mathrm{H} / 2 \mathrm{~V}$ on the facades where vertical curtain excavation is performed and no slope is recommended in the place where vertical curtain excavation is made. 


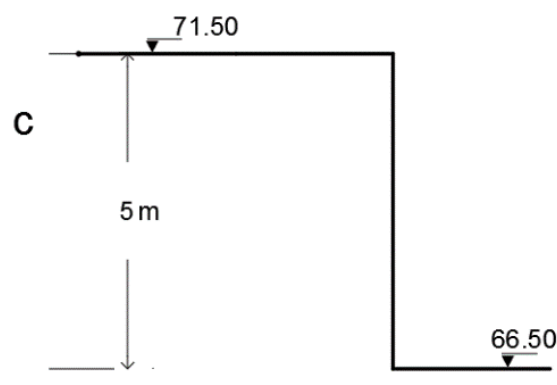

(c)

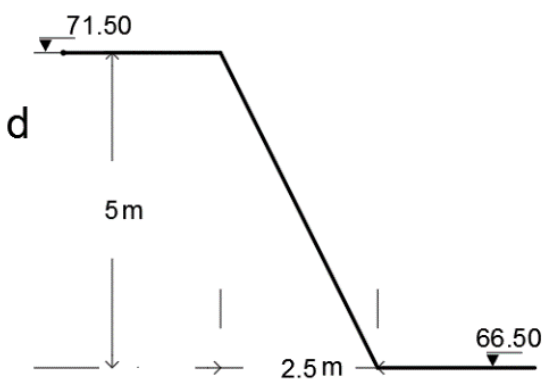

(d)

Figure 7. $\boldsymbol{c}$ and $\boldsymbol{d}$ sections with maximum elevation to be formed during 2 nd basement excavation.

In order to achieve the objectives of this study, Rocscience Slide 6.0 software is used. Slide is a 2D limit equilibrium slope stability software for the assessment of the safety factor or probability of failure, of circular or non-circular failure surfaces in soil or rock slopes. Rocscience Slide 6.0 analyzes the stability of slip surfaces using vertical slice or non-vertical slice limit equilibrium methods [22].

In this study, simplified Bishop method is adopted. The simplified Bishop method was proposed by Bishop (1955) [23]. Limit equilibrium methods have been used for decades to safely design major geotechnical structures. Bishop's simplified method, using a circular arc slip surface, is probably the most popular method [24]. Bishop's Simplified method (1955), use an estimated factor of safety when computing the normal force at the base of a slice [25]. Characteristics of bishop method are show in Table 2 .

Table 2. Characteristics of equilibrium methods of slope stability analysis [26].

\begin{tabular}{l|l}
\hline \hline Method & Characteristics \\
\hline \hline Bishop's Modified Method (Bishop 1955) & $\begin{array}{l}\text { This method is used for circular } \\
\text { slip surfaces } \\
\text { Provides moment equilibrium }\end{array}$ \\
\hline
\end{tabular}

This method satisfies vertical force equilibrium for each slice and overall moment equilibrium about the center of the circular trial surface. The method also assumes zero interslice shear forces [27]. In the simplified Bishop procedure, the forces on the side of the slice are assumed to be horizontal (i.e., there are no shear stresses between slices). Forces are summed in the vertical direction satisfy equilibrium in this direction and to obtain an expression for the normal stress of the base of each slice (Figure 8) Bishop's method is suited to most stability problems where a circular failure surface is likely. It is easy to run and always produces a result, since it only considers moment equilibrium [28,29]. 


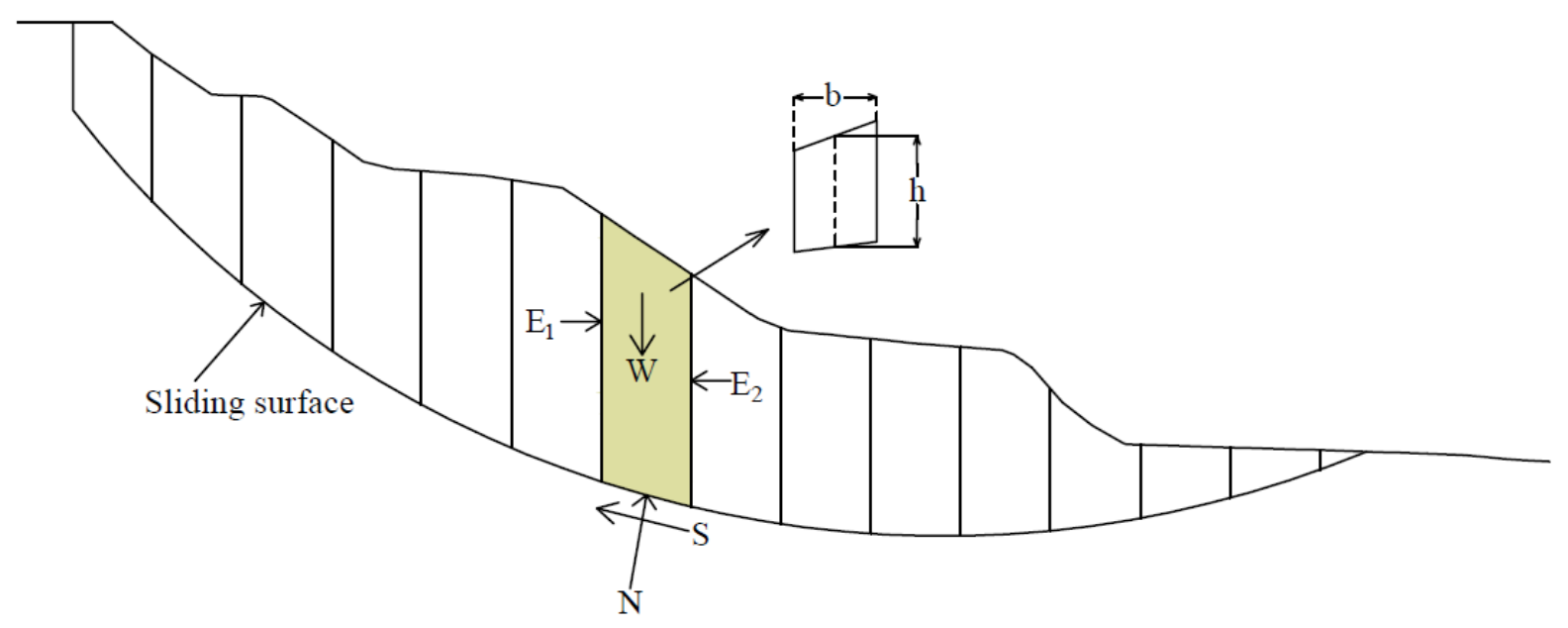

Figure 8. Forces acting on the slice, Bishop (1955) (drawn by the author) [30].

$\mathrm{S}$ is the available shear strength and $\mathrm{N}$ is normal force in the plane [31]. A simple form of the Bishop's simplified factor of safety equation is:

$F S=\frac{1}{\sum W \sin \alpha} \sum\left[\frac{c \beta+W \tan \varphi-\frac{c \beta}{F S} \sin \alpha \tan \varphi}{m_{\alpha}}\right]$

Factor of safety is on both sides of the equation as noted above. The equation is not much different than the ordinary factor of safety equation except for the $\mathrm{m}_{\alpha}$ term, which is defined as:

$m_{\alpha}=\cos \alpha+\frac{\sin \alpha \tan \varphi}{F S}$

Where,

$\mathrm{b}:$ width of slice

$\mathrm{w}$ : weight of slice,

$\mathrm{c}:$ cohesion

$\varphi$ : angle of internal friction

$\alpha$ : inclination of slice base.

FoS : Factor of safety [26].

\section{STABILITY ANALYSIS}

Stability analysis was performed for the 1 st and 2nd basement excavations mentioned in the foundation excavation. In the 1 st basement excavation, the stability calculations for the beveled excavation with a slope of $1 \mathrm{H} / 2 \mathrm{~V}$ were finalized and it was observed that the stability was achieved thanks to the calculations. According to the stability calculation results, the factor of safety obtained in the $1 \mathrm{st}$ basement excavation on the facade with optional slope was calculated as 1.593 (Figure 9b).

The stability analysis performed on the facade where the vertical curtain will be constructed in the 1st basement excavation has shown that the factor of safety is calculated as 1.257 (Figure 9a). Considering the hydrostatic effects that may occur from underground and surface waters on this facade, measures should be taken in terms of construction safety. Prospective measures are given in the results section. 


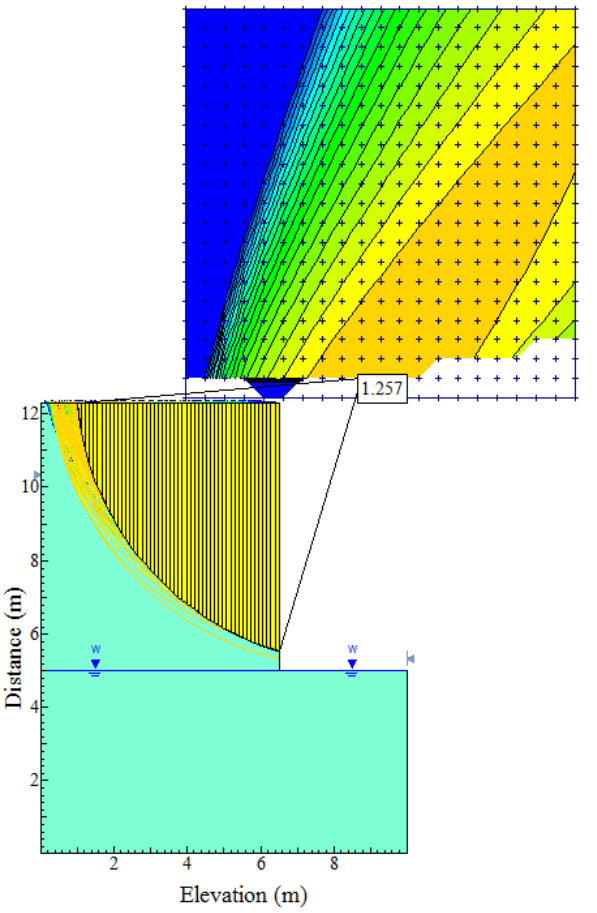

(a)

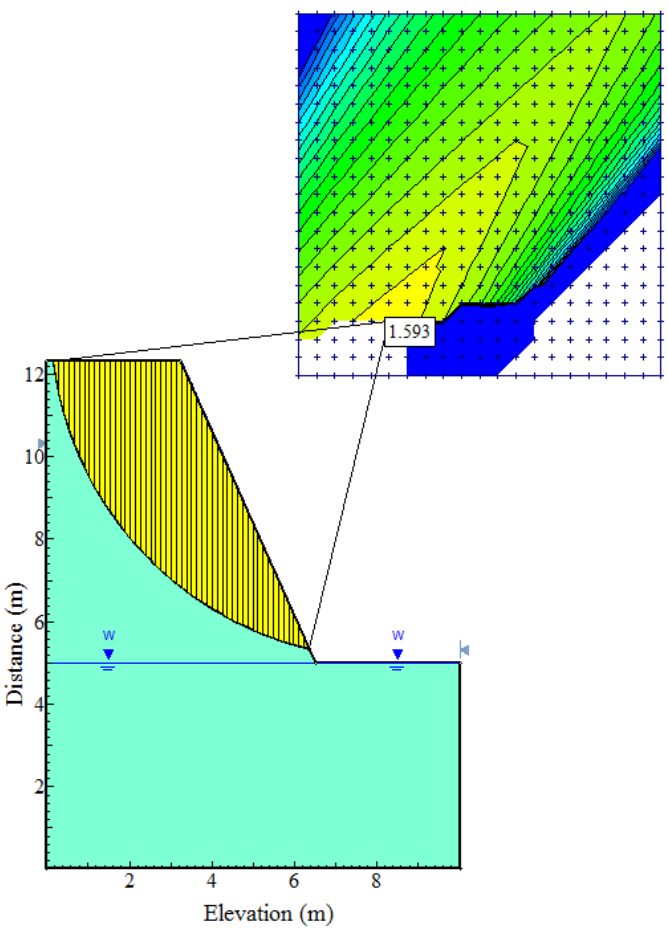

(b)

Figure 9. 1st basement vertical curtain excavation façade (a) 1st basement excavation façade with an optional slope $(\boldsymbol{b})$.

For the 2nd basement excavation, the stability calculations for the beveled excavation with $1 \mathrm{H} / 2 \mathrm{~V}$ slope on the facades with optional slopes shown in Figure 10a have been finalized and it has been observed that the stability has been achieved thanks to the calculations. In addition, it was obtained as a result of the analysis that stability was ensured in the vertical wall excavation of the 2 nd basement excavation. Following the analyses, the factor of safety on the facade where the vertical curtain will be excavated was calculated as 1.669 and the factor of safety obtained as a result of the analysis performed on the facade where the slope could be constructed was calculated as 2.238 (Figure 10). 


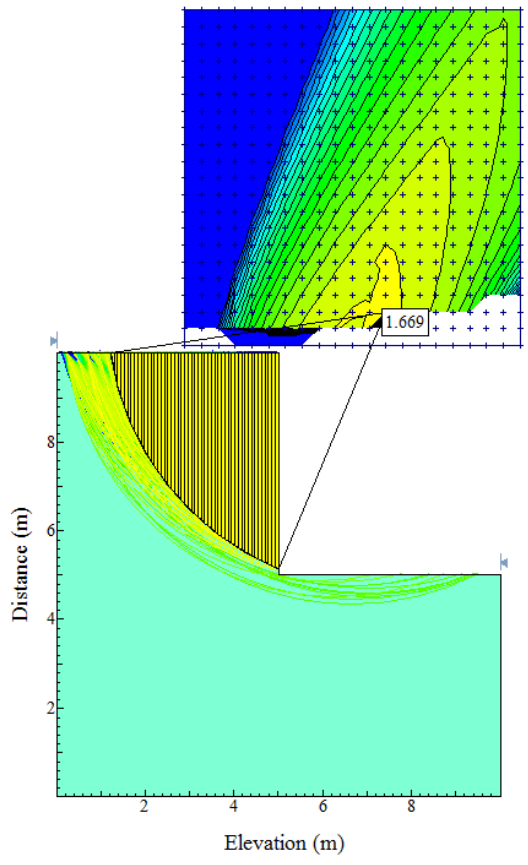

(a)

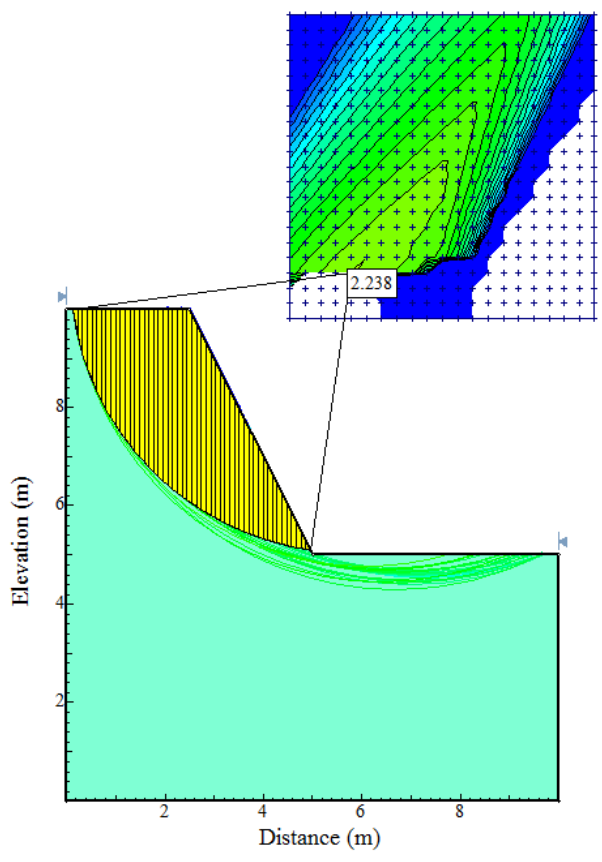

(b)

Figure 10. 2nd basement vertical curtain excavation façade (a) 2nd basement excavation façade with optional slope $(\boldsymbol{b})$.

\section{CONCLUSION AND RECOMMENDATIONS}

The current study focuses on the evaluation of slopes in static condition. The soils exposed on the sites were mainly of Sariyer formation. Limit equilibrium analysis was performed with software Slide v. 6.0 to assess factor of safety of slopes at static conditions.

Stability analysis was carried out under two different conditions as steep and slope excavation. In the second basement excavation, it was observed that the factor of safety was stable with the results of 2.238 and 1.169 in the analysis made in the excavations on the sloped and vertical curtain facade. During the 1 st basement excavation, the factor of safety on the vertical curtain excavation facade was calculated as 1.257. Numerical analysis shows that the vertical curtain excavation is unstable with less than 1 factor of safety, and the sliding surface occurred at the ground interface.

The following recommendations were deduced from the results of the analysis:

- In the foundation excavations to be started, precautions to prevent surface water from infiltrating the ground should be taken into consideration primarily. The construction of the basement curtain has gained importance immediately after the excavation, as the stability may deteriorate with the hydrostatic effects that may occur from rainfall, underground and surface waters.

- In case of extensions during the construction, additional measures such as shotcrete can be taken.

- Under normal conditions, soils may be stable, but with excavation, the stability can become very sensitive.

- Before starting the excavation work, the geotechnical study of the excavation area should be done and the soil type, layers and water level should be determined. 
- In order to increase the factor of safety, additional measures should be taken on the slope in the excavation area.

- The stability problem must be examined in excavation works, and excavation works should be allowed after the necessary precautions are taken within a project.

ACKNOWLEDGEMENTS: Finally, the author would like to thank to Kazım Gökhan ELGIN for providing data for this paper and to Assoc. Prof. Dr. Arzuhan Burcu GÜLTEKIN from Gazi University for supporting this project to be published.

\section{REFERENCES}

[1] M. Erdik and E. Durukal, "Earthquake risk and its mitigation in Istanbul," Natural Hazards, vol. 44, no. 2, pp. 181-197, 2008.

[2] B. Torus and N. Aydin, "Urban transformation in Istanbul," 4th International Conference ArchiCultural Interactions, Nishinomiya, Japan, July 16-18, 2016.

[3] R. Lutton, "A mechanism for progressive rock mass failure as revealed by loess slumps," International Journal of Rock Mechanics and Mining Sciences and Geomechanics, vol. 8 no. 2, pp. 143149, 1971.

[4] B. Burland, T. Longworth and F. Moore, "A study of ground movement and progressive failure caused by a deep excavation in Oxford Clay," Géotechnique, vol. 14 no. 6, pp. 557-591, 1977.

[5] A Ö. Erçin, "Slope Stability and Engineering Applications," M.S. thesis, Department of Civil Engineering, Erciyes University, Kayseri, Turkey, 2007.

[6] D. Varnes, "Slope movements: types and processes in Schuster," Landslides, vol. 36 no. 3, pp. 11-33, 1978.

[7] D. Cruden and M. Varnes, "Landslides types and processes," Landslides, vol. 201, no. 4, pp. 36-57, 1996.

[8] P. Canuti, P. Focardi and C. Garzoni, "Correlation between rainfall and landslides," Bulletin of Engineering Geology and the Environment, vol. 32, no. 8, pp. 49-54, 1985.

[9] J. Corominas and J. Moya, "Reconstructing recent landslide activity in relation to rainfall in the Llobregat River basin," Geomorphology, vol. 32, no. 21, pp. 79-93, 1999.

[10] C. Zhou, C. Lee, J. Li and Z. Xu, "On the relationship between landslides and causative factors on Lantau Island, Hong Kong,” Geomorphology, vol. 43, no. 4, pp. 197-207, 2002.

[11] Q. Zaruba and V. Mencl, Landslides and Their. Control. Amsterdam, NX: Elsevier.1982.

[12] F. Zhang, G. Liu, W. Chen, S. Liang, R. Chen and W. Han, "Human-induced landslide on a high cut slope: a case of repeated failures due to multi-excavation," Journal of Rock Mechanics and Geotechnical Engineering, vol. 4, no. 4, pp. 367-374, 2012.

[13] A. E. Erginal, M. Türkeş, T. A. Ertek, A. Baba and C. Bayraktar, "Geomorphological investigation of the excavation-induced Dündar landslide, Bursa - Turkey," Physical Geography, vol. 6, no. 2, pp. 109-123, 2008. 
[14] M. Li, G. Zhang and Y. Hu, "Centrifuge model tests on excavation-induced failure of slopes," Rock and Soil Mechanics, vol. 31 no. 2, pp. 366-370, 2010.

[15] J. Wang, Y. Liang and H. Zhang, "A loess landslide induced by excavation and rainfall," Landslides, vol.11, no. 1, pp. 141-152, 2014.

[16] S. Mohammadi and H. Taiebat, "Finite element simulation of an excavation-triggered landslide using large deformation theory," Engineerin Geology, vol. 205, no. 8, pp. 62-72, 2016.

[17] Y. Sutejoa and G. Nurly, "Effect of area development on the stability of cut slope," The 5th International Conference of Euro Asia Civil Engineering, Surabaya, Indonesia, Sep. 15-18, 2015.

[18] Google Maps. (2020, Nov 14). School location image [Online]. Available:https://www.google.com/earth.

[19] R. Korkmaz and M. Tekin, "İstanbul İl Alanının Jeolojisi,” İstanbul Büyükşehir Belediyesi Deprem Risk Yönetimi ve Kentsel İyileştirme Daire Başkanlığı, Rap.12, 2011.

[20] Y. Hayata, NII-Electronic library service. Chemical Pharmaceutical Bulletin, vol. 43, no. 56, pp. 2091-2016, 2002.

[21] S. S. Tezcan, A. Keceli and Z. Ozdemir, "Allowable bearing capacity of shallow foundations based on shear wave velocity," Geotechnical and Geological Engineering, vol. 21, no. 1, pp. 203-218, 2006.

[22] Rocscience Slide 6.0, Computer Software, Toronto (ON), 2014.

[23] B. Georges, H. Shimizu and S. Nishimura, "Residual strength of colluvium and stability analysis of farmland slope," The Commission International Du Genie Rural Journal, vol. 14, no. 2, pp. 1-12, 2001.

[24] J. Han and D. Leshchinsky, "Limit equilibrium and continuum mechanics-based numerical methods for analyzing stability of mse walls," 17th ASCE Engineering Mechanics Conference, Newark, United States, Jun 12-16, 2004.

[25] D. G. Fredlund and R. E. Scoular, "Using limit equilibrium concepts in finite element slope stability analysis," Slope Stability Engineering, vol. 35, no. 25, pp. 31-47, 1999.

[26] R. W. Day, "State of the art: Limit equilibrium and finite-element analysis of slopes," Journal of Geotechnical and Geoenvironmental Engineering, vol. 123, no. 9, pp. 894-899, 1997.

[27] M. Rabie, "Comparison study between traditional and finite element methods for slopes under heavy rainfall," HBRC Journal, vol. 10, no. 2, pp. 160-168, 2014.

[28] K. Baba, L. Bahi, O. Latifa and A. Akhssas, "Slope stability evaluations by limit equilibrium and finite element methods applied to a railway in the moroccan rif," Open Journal of Civil Engineering, vol. 5, no. 2, pp. 12-27, 2012.

[29] Z. S. Mansour and B. Kalantari, "Traditional methods vs. finite difference method for computing safety factors of slope stability," Electronic Journal of Geotechnical Engineering, vol. 18, no. 6, pp. 1119-1130, 2011.

[30] J. M. Duncan and S. G. Wright, Soil strength and slope stability, John Wiley and Sons, Eds. New Jersey: Hoboken Press, 2005, pp. 205-220. 
[31] Geo-Slope International Ltd. SLOPE/W user's manual. Version 4.0. Copyright. Geo-Slope International Ltd., Calgary, Alta. 2001, pp. 1991-2001. 